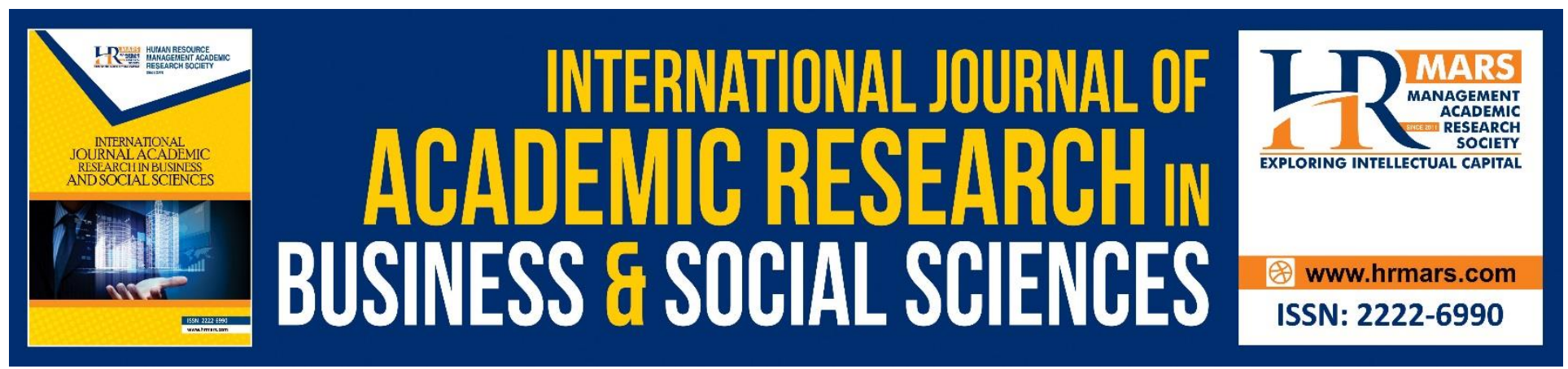

\title{
Magnitude of Role-Breadth Self-Efficacy in Teacher Proactive Work Behaviour
}

\section{Suguna Devi Peariasamy, Zoharah Omar, Ramli Basri, Siti Noormi Alias}

To Link this Article: http://dx.doi.org/10.6007/IJARBSS/v10-i7/7434

DOI:10.6007/IJARBSS/v10-i7/7434

Received: 05 April 2020, Revised: 09 May 2020, Accepted: 12 June 2020

Published Online: 20 July 2020

In-Text Citation: (Peariasamy et al., 2020)

To Cite this Article: Peariasamy, S. D., Omar, Z., Basri, R., \& Alias, S. N. (2020). Magnitude of Role-Breadth SelfEfficacy in Teacher Proactive Work Behaviour. International Journal of Academic Research in Business and Social Sciences, 10(7), 446-459.

\section{Copyright: (C) 2020 The Author(s)}

Published by Human Resource Management Academic Research Society (www.hrmars.com)

This article is published under the Creative Commons Attribution (CC BY 4.0) license. Anyone may reproduce, distribute, translate and create derivative works of this article (for both commercial and non-commercial purposes), subject to full attribution to the original publication and authors. The full terms of this license may be seen at: http://creativecommons.org/licences/by/4.0/legalcode

Vol. 10, No. 7, 2020, Pg. 446 - 459

http://hrmars.com/index.php/pages/detail/IJARBSS

JOURNAL HOMEPAGE

Full Terms \& Conditions of access and use can be found at http://hrmars.com/index.php/pages/detail/publication-ethics 


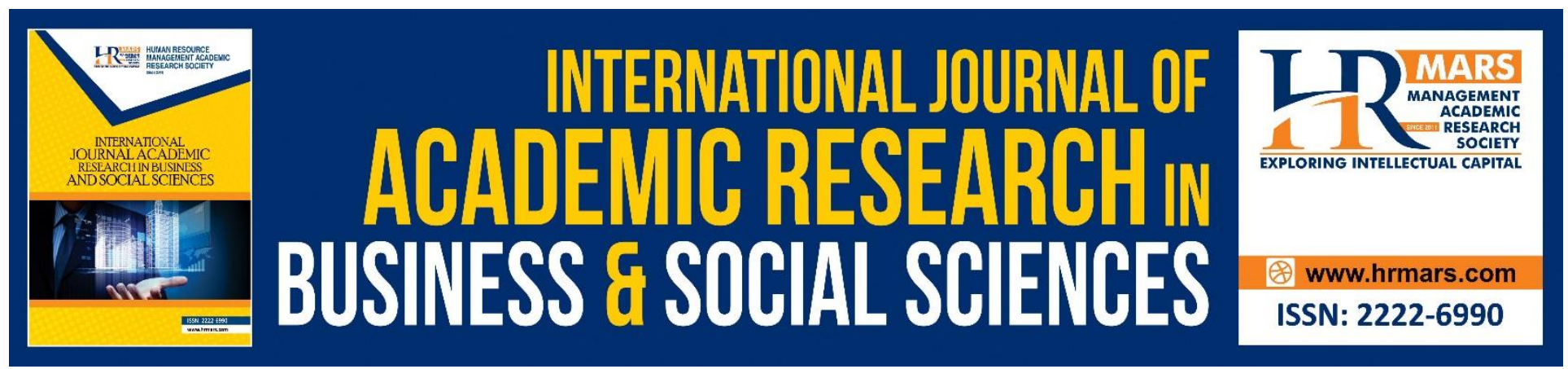

\title{
Magnitude of Role-Breadth Self-Efficacy in Teacher Proactive Work Behaviour
}

\author{
Suguna Devi Peariasamy, Zoharah Omar \\ Department of Professional Development and Continuing Education, Universiti Putra Malaysia \\ Email: sugunadevi72@yahoo.com,zoharah@upm.edu.my \\ Ramli Basri \\ Faculty of Educational Studies, University Putra Malaysia \\ Email: ramlibasri@upm.edu.my \\ Siti Noormi Alias \\ Department of Professional Development and Continuing Education, Universiti Putra Malaysia \\ Email: sitinoormi@upm.edu.my
}

\begin{abstract}
Proactive behaviour at work (PWB) is aimed at bringing about change within the organization, such as by improving work methods, voicing ideas or concerns, and taking action to prevent problems from reoccurring (Strauss \& Parker, 2014). PWB can add to organizational effectiveness (Axtell et al., 2000; Griffin et al., 2007; Rank, Pace, \& Frese, 2004) and is especially important in school setting when teachers come into contact with students proactively and make them understand what is being taught clearly (Devonport, Biscomb, \& Lane, 2010; Sheard \& Carbone, 2008). Proactive behaviour in daily work is the quality that teachers must possess in order to make the education system more successful. Strauss (2015) highlighted that, in $21^{\text {st }}$ century teaching and learning practices that emphasis flexibility, innovation and adaptation to changes. School organizations are rapidly looking for competencies and behaviours in teachers who can facilitate and adapt to new educational challenges. Teacher role-breadth self-efficacy (RBSE) is specifically important to meet the current demand in education and help teachers to prepare for future challenges. RBSE is more substantial in academic world today as teachers are expected to take a proactive role to the extent to feel confident and able to carry out broader role that is beyond the traditionally described self-efficacy (Parker, 1998)
\end{abstract}

Keywords: Proactive Work Behaviour, Proactive Teacher, Role-Breadth Self-Efficacy, Self-efficacy, School Effectiveness 
INTERNATIONAL JOURNAL OF ACADEMIC RESEARCH IN BUSINESS AND SOCIAL SCIENCES Vol. 10, No. 7, July, 2020, E-ISSN: 2222-6990 @ 2020 HRMARS

\section{Introduction}

As organizations grow increasingly complex and unpredictable, the topic of proactivity at work has become a great importance for contemporary workplaces (Parker \& Bindl, 2017). In school settings, to meet the current demand, teachers need to committedly engage in their work by taking leadership in improving situations and overcoming challenges rather than passively adapting to existing condition. Pei Ling (2016) stressed teachers today, are constantly facing challenges in their job as a result of the changes in the education system in which they have to adapt. Under these conditions, the schools are becoming more dependent on teachers to contribute to school effectiveness regardless of formal job requirements (DiPaola and Hoy, 2005). The behavior that teachers do that go beyond the assigned task and change oriented, is proactive behavior at work (Cerit, 2017).

The importance of PWB must be brought to the knowledge of every teacher to improve the quality and the performance of schools. PWB is one of the specific behaviours that is needed to improve current circumstances. It involves challenging the status quo rather than passively adapting to present conditions (Crant, 2000; Bindle \& Parker, 2012; Grant \& Asford, 2008). This behaviour is selfstarting, driven by problems or opportunities and aim at improving the overall work condition (Fay and Sonnentag, 2012). But the question arises as how to encourage and develop PWB among teachers. Past studies focused more on promoting either task performance or contextual performance and organizational citizenship behaviour (Axtell \& Parker, 2003) Contextual performance and organizational citizenship behavior (OCB) provide dimensions considered quite passive or reactive in their orientation, such as compliance with organizational procedures (George \& Brief, 1992; Speier and Frese, 1997). Much less research has focused on how to promote workplace proactivity, such as what motivational or cognitive processes underpin this change

Past studies have reported several individual factors that influence teachers' PWB. Among the most significant individual factor is RBSE that have shown to have a positive influence on PWB. It is a strong predictor of PWB such as individuals managing their immediate work environment, make suggestions for how the team might work with people, come up with new procedures for their job, or they take charge to bring about change in their work (Axtell, Holman, Unsworth, Wall, Waterson \& Harrington, 2000). Additionally, RBSE is an important predictor of employees' innovation (Axtell et al., 2000; Siegel and Renko, 2012) and proactive performance (Griffin, Parker \& Neal, 2002). Various studies indicated that self-efficacy is an important predictor of proactive behaviours: personal leadership and taking charge (Morrison \& Phelps, 1999). It is timely to look at the significance of RBSE which focuses on the confidence level of carrying a broader and more proactive role specifically in teaching profession.

\section{Proactive Work Behaviour Outlook}

Proactive behaviour at work is among the three higher order categories of proactive behaviour that is referred to as proactive work behaviour (PWB) by Parker and Collins (2010). PWB is aimed at bringing about change within the organization, such as by improving work methods, voicing ideas or concerns, and taking action to prevent problems from reoccurring (Strauss \& Parker, 2014). PWB has been proposed as active behavior that is initiated by the individual, focused on bringing positive change in themselves or their environment, and future focused (Grant \& Ashford, 2008; Parker, Bindle, \& Strauss, 2010). 
PWB is defined as taking charge, voice, individual innovation, and problem prevention which are proactive behaviours that focuses on taking control, and bringing about change within, internal organisational environment such as by improving work methods or influencing work colleagues. Morrison and Phelps (1999) indicated that taking charge concerns constructive efforts by employees to effect organizationally functional change with respect to how work is executed. It is illustrated by the behaviour of "trying to bring about improved procedures in your workplace." Similarly, voice is concerned with speaking out about issues that affect one's work group as well as seeking information about such issues (Dyne \& LePine, 1998). As for taking charge, it is the intended target of the impact of voice. Individual innovation (Scott \& Bruce, 1994) is said to be distinct from both taking charge and voice because of its emphasis on novelty, but in common with these behaviours the aim of influencing one's internal work environment. Lastly, problem prevention focuses on dealing with the reoccurrence of challenges and barriers in the work environment. It is self-directed and anticipatory action to prevent the reoccurrence of work problems (Frese \& Fay,2001)

\section{Role-breadth Self-efficacy Outlook}

Bandura (1997) describes self-efficacy as beliefs in one's capabilities to organize and execute the course of action required to produce given attainments. Later Parker (1998) described RBSE as "the employees' perceived capability of carrying out a larger set of work tasks". When task related selfefficacy is high the likelihood of completing a task will be higher because it increases the drive to complete and succeed (Axtell \& Parker, 2003). RBSE refers to the extent to which people feel confident that they can carry out a broader and more proactive role, beyond traditional prescribed technical requirements' (Parker, 1998). The concept has a broader focus than other forms of selfefficacy that are typically concerned with a specific task or activity. An employee with RBSE tends to focus on a variety of proactive, integrative, and interpersonal relational activities that make up an expanded role such as addressing long-term problems, implementing improved procedures, and contacting customers and suppliers. It varies from the idea of such as contextual performance, OCB, and prosocial behavior towards organization (Borman \& Motoviwildo, 1993; Mcneely \& Meglino, 1994; Organ, 1988). RBSE is more concerned with a person's perceived capability to perform these tasks and behaviors.

Unlike proactive personality, which is a relatively stable personal disposition, RBSE is expected to change as environmental conditions and employees' organizational experiences change. It has been noted that to handle environmental dynamism, organizations need skilled employees who are both able and willing to take on a broader role. RBSE is a different construct which focuses on what people do or behave, but rather on what they feel they can do. It clearly focuses on task that requires employees to be proactive whereas for concepts such as organizational citizenship behaviour that includes dimensions like being more passive in orientation such as complying with the procedures, punctuality and attendance (George \& Brief, 1992). The concept of RBSE is also distinct from selfesteem, whereby it is well thought as a global trait reflecting an individual's characteristic and affective evaluation of the self. Brockner (1988) stressed that self-efficacy, conversely, is a judgment about specific task capability. Self-efficacy (and hence RBSE) is a dynamic construct that changes over time, unlike self-esteem which is seen as a stable trait (Brockner, 1988; Wood \& Bandura, 1989). 
INTERNATIONAL JOURNAL OF ACADEMIC RESEARCH IN BUSINESS AND SOCIAL SCIENCES Vol. 10, No. 7, July, 2020, E-ISSN: 2222-6990 @ 2020 HRMARS

Together with recent growth citizenship behavior research and proactive expanded roles, this literature is likely to be an important explanatory construct for teacher proactive work behavior in school organizations. In this article, we focus on how RBSE affects the PWB of teachers.

\section{The Influence of Role-breadth Self-efficacy on Proactive Work Behavior}

RBSE is a significant predictor of PWB. By raising one's confidence and feeling of control the person will choose more difficult goals because the perceived likelihood of success is greater (Parker \& Collins, 2008). Their confidence is high enough to proactively challenge the status quo and trying to improve current circumstances. They move away from their comfort zone and being persistent in overcoming difficulties in order to reach their goal and thus show a more proactive role (Frese \& Fay, 2001).

Organizations increasingly demand for capable employees who can take on broader and more proactive work roles (Bateman \& Crant, 1993; Dean \& Snell, 1991). RBSE has been found to be an important predictor of employee innovation (Axtell et al., 2000). Griffin et al. (2002) found that RBSE was the strongest predictor of proactive performance relative to other predictors, and that other types of performance (task and adaptive performance) were influenced more by other antecedents. Studies have also shown that self-efficacy is an important determinant of two dimensions of proactive behaviour: personal initiative (Fay \& Frese, 2001; Frese et al., 1996; Speier \& Frese, 1997) and taking charge (Morrison \& Phelps, 1999). RBSE is expected to change as environmental conditions and employees' organizational experiences change. While PWB requires both risk taking and effort, individuals' RBSE is particularly important for these behaviours (Parker, 1998, 2000).

RBSE, or one's judgement about one's capability to perform particular tasks, is a critical work motivation variable (Gist \& Mitchell, 1992). Individuals who feel capable of performing particular tasks tend to carry them out more effectively (Barling \& Beattie, 1983), persist at them (Lent, Brown, \& Larkin, 1987), cope more effectively with change (Hill, Smith, \& Mann, 1997), choose more difficult goals (Locke \& Latham, 1990), and adopt more efficient task strategies (Wood, George-Falvy, \& Debowksi, 2001). Because it raises one's feelings of control and the perceived likelihood of success, self-efficacy is seen as crucial for PWB like initiative (Speir \& Frese, 1997) and taking charge (Morrison \& Phelps, 1999) as well as for related behaviours such as voice (Whithey \& Cooper, 1989).

RBSE is shown to be associated with outcomes such as proactive work performance (e.g., Griffin et al., in press) and making improvements and suggestions (Axtell et al., 2000). Researchers have adopted a number of different approaches toward identifying the antecedents and consequences of PWB, and they have examined them in a number of separate literatures. It is shown to have a significant relationship with PWB (Belschak \& Den Hartog, 2010; Den Hartog \& Belschak, 2012; Strauss, Griffin, \& Allannah, 2009; Parker, Turner, \& William, 2006). For constant changing world and organizational success, organizations are increasingly demand for employees who can take on broader and more proactive work roles (Bateman \& Crant, 1993; Dean \& Snell, 1991). 
INTERNATIONAL JOURNAL OF ACADEMIC RESEARCH IN BUSINESS AND SOCIAL SCIENCES Vol. 10, No. 7, July, 2020, E-ISSN: 2222-6990 @ 2020 HRMARS

\section{Theoretical Underpinning}

Drawing mainly on Self Determination Theory (SDT) (Deci \& Ryan, 1985), and the Motivation Model of Individual Level of Proactive Work Behavior (PWB) proposed by Parker, Bindle and Strauss (2010), this literature outlines and develops the current conceptualizations of how RBSE influence PWB. Central to SDT is the distinction between autonomous motivation and controlled motivation (Deci, Olafsen \& Ryan, 2017). Autonomy involves acting with a sense of volition and having the experience of choice. Intrinsic motivation is an example of autonomous motivation. When people engage in an activity because they find it interesting, they are doing the activity wholly volitionally (e.g., I work because it is fun). In contrast, being controlled involves acting with a sense of pressure, a sense of having to engage in the actions. SDT postulates that autonomous and controlled motivations differ in terms of both their underlying regulatory processes and their accompanying experiences, and it further suggests that behaviors can be characterized in terms of the degree to which they are autonomous versus controlled. Autonomous motivation and controlled motivation are both intentional, and together they stand in contrast to amotivation, which involves a lack of intention and motivation. Motivation is the driving force that causes someone to make decisions and those decisions are influenced intrinsically and extrinsically by social context when an individual is exposed to society (Richard \& Schmidt, 2002). Bartol and Martin (1998) consider motivation as a powerful tool that reinforces behavior and triggers the tendency to continue. In other words, motivation is an internal drive to satisfy an unsatisfied need and to achieve a certain goal. It is also a procedure that begins through a physiological or psychological need that stimulates a performance set by an objective.

Grounded on Self-determination Theory, Parker, Bindle, \& Strauss (2010) emanated Motivation Model of PWB that clarifies how RBSE an individual factor variable has effect on employees' PWB that is influence by proactive motivational states and goal process. They identified three different proximal motivational states through which PWB is influenced. They include 'can do' motivation, where employees believe that they can significantly influence outcomes (Frese \& Fay, 2001) and their success is pinned on their PWB (Parker, 2000); and the 'reason to' motivation, where employees have a convincing reason to engage in a PWB (Vroom, 1964); and the 'energized to motivation, where employees feel energized through the experience of the effect of high-activation (Strauss \& Parker, 2014).

It has been proposed by Parker et al., (2010) that proactive goal generation and striving will depend on whether individuals feel capable of being proactive (a 'can do' pathway), whether they have some sense that they want to bring about different future (a 'reason to' pathway), and whether they have some positive affect to foster their proactive actions (an 'energized to' pathway). These three motivational mechanisms are consistent with the motivational system theory (Ford, 1992) by mapping on the three forces in an individual's motivation system: personal agency belief, intrinsic motivation, and emotional force. SDT promotes the understanding of the abovementioned state, thus offering significant insights into how PWB can be motivated.

A critical part of the 'can do' motivation state is the belief in one-self can be proactive, represented by self-efficacy perceptions. Being proactive is potentially uncertain and risky, therefore individuals need to have the self-confidence to initiate proactive goals and deal with negative consequences 
induced by such proactive behavior. Indeed, many studies supported that self-efficacy later RSBE which addresses one's perceived capability of carrying out a broader and more proactive role beyond technical requirements (Parker, 1998) appears to be particularly important for proactivity. In addition, 'can do' motivation also includes the belief that one can control the situation and will produce desired outcomes, as well as perceptions about the negative aspects of engaging in a task, such as fear of failures and worry about lacking the required resources. 'Reason to' motivation state is when people feel confident about their ability to generate and implement something new (having 'can do' motivation), yet there is no compelling reason for them to do so (lacking 'reason to' motivation), it is unlikely they will engage in PWB. Unlike prescribed tasks where a reason is already given as part of one's job, proactive activities are self-initiated and thus the reason to engage in these activities cannot be assumed. Considering also the risk and uncertainty associated with proactivity, there needs to be strong rationale that drives an individual to make new things happen. The third motivational state 'energized to' for proactive behavior is affect-related. How people feel can provide an 'energizing' fuel that motivates individuals to engage in proactive behavior. Compared to the other two 'cold' motivations that are cognitively bound, the emotion-laden motivation is more of a 'hot' psychological force for proactivity. Individuals' core affects are usually considered to be represented by an integral blend of two primary dimensions: pleasure whether an affect is positive/pleasant or negative/unpleasant in its affective valence and arousal. Whether an affect is highly activated or lowly activated (Russell, 2003) in its arousal. Under the influence of positive affect people are more likely to reach out and set proactive goals, as well as remain open minded and flexible when pursuing their proactive goals.

In regard to, 'can do' 'reason to' and 'energized to' states motivate the setting of proactive goals and/or striving to achieve these goals. Both 'can do' and 'reason to' states need to align with the particular target. Although identified motivation is apparent, an individual might proactively aim to improve the way his or her team works because working in positive atmosphere is very important, whereas another individual might negotiate new projects opportunities because getting ahead in his or her career is very important. It has been suggested that the reasons for proactivity extend beyond the pure involvement. An individual might introduce a new work method because he or she enjoys his or her work so immensely (intrinsic motivation) and his or her job is so central to him or her that improving its effectiveness is part of "who he or she is" (integrated motivation). Parker at el., (2010) suggested that activated positive affect stimulates the pursuit of proactive goals regardless of the envisioned future state or locus of change. The 'can do' 'reason to' and 'energized to' are three important motivational states in which influences individual PWB (Parker at el., 2010).

According to Parker, Bindle, and Strauss (2010) intrinsic motivation stipulates different types of autonomous motivation that drives an individual goal process. Individuals are more likely to strive for more proactive goals if they find their tasks intrinsically interesting and generally enjoyable. Past researchers proposed that autonomously regulated motivation increases the likelihood that proactivity results in positive change for both individuals and organizations. Autonomously regulated proactivity involves a more complete goal regulation process and a greater sense of ownership and involvement of the self, thus making it more likely for proactive goals to be achieved. 
INTERNATIONAL JOURNAL OF ACADEMIC RESEARCH IN BUSINESS AND SOCIAL SCIENCES Vol. 10, No. 7, July, 2020, E-ISSN: 2222-6990 @ 2020 HRMARS

The concept of proactivity at work most strongly expresses this view of organizations as environments of and for human agency. Proactivity involves challenging the current situation and working towards what 'could be'. Specifically, being proactive reflects self-starting and futurefocused action that aims to bring about change, either in the self or in one's work environment (Parker et al., 2010). This conceptualization of behavior in organizations emphasizes intentionality and forethought, and acknowledges that individuals are not always merely motivated by tangible reward contingencies. Proactivity makes room for individual goals that are not tied to external rewards but are pursued because they are interesting, highly valued, or reflect authentic and interests. Correspondingly, proactive individuals experience a greater sense of self-determination in their lives (Greguras \& Diefendorff, 2010; Seibert, Crant, \& Kraimer, 1999).

In this study RBSE, from SDT perspective is an optimal challenge which are concerned with competence that contributes to intrinsic motivation. RBSE is about the feeling of confident that they can carry out a broader and more proactive role, beyond traditional prescribed technical requirements' (Parker, 1998). Individual belief is autonomous and self-determination is intrinsic, selfsustaining form of motivation that is influenced by internal stimuli (Deci \& Ryan, 1985; Ryan \& Deci, 2000). Guided exclusively by inner drives, self-determined individuals seek to satisfy three primary needs in order to optimize their goal potentials: competence, autonomy, and psychological relatedness (Deci \& Ryan, 1985). According to Deci and Vansteenkiste (2004), self-determined individuals internalize their ability to control behavior and satisfy mastery needs (i.e., competence), perceive themselves as causal agents of their destinies (i.e., autonomy), and are inclined toward assimilation with others (i.e., relatedness). More specifically, in order for one to be intrinsically motivated to engage in an activity one needs to feel competent (e.g., the activity offers optimal challenges and relevant feedback) to carry out the activity and feel that the reason they engaged in the activity was not because of external pressure or control Deci \& Ryan (1985). Past studies have shown (Fisher, 1978; Ryan, 1982), that feelings of competence will not enhance intrinsic motivation unless accompanied by a sense of autonomy (deCharms, 1968). Thus, people must not only experience competence or efficacy, they must also experience their behaviour as self-determined for intrinsic motivation to be in evidence. This requires either immediate contextual supports for autonomy and competence or abiding inner resources (Reeve, 1996) that are typically the result of prior developmental supports for perceived autonomy and competence. RBSE is the concept of intrinsic motivation, that is the central concept for behavioural change which is "based on the satisfactions of behaving 'for its own sake' (Ryan \& Deci, 2017).

\section{Proactive Work Behaviour for Effective School}

In ensuring school effectiveness, proactive teachers are the vital workforce in achieving the educational policy that aims in enhancing the quality of education and developing nation's human capital. PWB is more important today than ever for both individual and organizational success. RBSE differs from common conceptualizations of self-efficacy that make up an expanded role will vary across jobs and companies. One key requirement in all organizations is for employees to be proactive and use their initiative (Buchanan \& McCalman, 1989; Frese et al., 1996). Consistent with Bandura's $(1982,1986)$ conceptualization, the emphasis of RBSE is on people's perception that they are able to carry out these types of tasks, rather than whether they are allowed to, or do, or perform 
them.Bandura (1997) reported that individuals with a high level of RBSE coped well with difficulties, set hard-to-reach goals for themselves, and put great energy into reaching these goals.

Traditionally, teacher self-efficacy is found in many literatures that gives a wide coverage to the concept of teachers' self-efficacy as teachers have many different responsibilities, and the expectations and beliefs of teachers regarding themselves and their students are considered important. Teacher self-efficacy is an important construct as it has a significant impact on student learning capacity, increases the students' expectations of their teachers, and has a leading role in improving the academic achievement of school as a whole (Bandura, 1995) but the later RBSE is more significant in academic world today as teachers are expected to take a broader role to the extent to feel confident and able to carry out broader and more proactive role that is beyond the traditionally described self-efficacy (Parker, 1998)

In this regard, it is important for school organizations to encourage teachers to have high RBSE and take individual responsibility and make problem-solving easier (Sinden et al., 2004). Hoy and Sweetland (2001) stated that in schools with teachers who have higher RBSE levels are regarded as professionals and are given the autonomy to fulfil their tasks effectively. Teachers with a higher RBSE may have more positive perceptions regarding the use of their knowledge, skills, and specialties to increase student achievement, take responsibility for their students' success and believe the reasons for failure are related to problems in their own teaching-learning activities. Past studies support that teacher self-efficacy later RBSE (Parker, 1998) is an important variable in teacher effectiveness that is consistently related to teacher behaviours and student outcomes (Bray \& Bates, 2003).

\section{Discussion}

In the $21^{\text {st }}$ century teaching and learning, teachers need this behaviour to lead instead of trailing behind, actively seek new ways of doing things and staying in. Despite the importance for teachers to engage in PWB, not many teachers are aware of the significance to have PWB (Ghitulescu, 2013). This review supports the idea that RBSE is important for teacher's PWB which is the future demand in effective school organizations. The literature suggests school leaders to take actions to promote and enhance teacher's RBSE that eventually lead to teacher PWB which is desired by most organizations. This is supported by Axtell et al., (2003) findings that managers can take actions to enhance employees' level of self-efficacy and thereby develop their potential that will ultimately enhance proactivity.

Secondly, this discussion will have some implications on teachers and principals especially influence the school practice by looking into ways to increase teachers' PWB. The review will help organizations especially school in the role of training the teachers. Parker (1998) in her studies found that training was not an important determinant of RBSE, but Axtell et all., (2003) in her studies found that incorporation of a broad range of training had significant impact on increased RBSE. This review suggest that school leaders can incorporate intervention or training programs to enhance teacher RBSE that can lead to a more proactive teacher behaviour. This review suggests that, if school organizations want to enhance PWB of their teachers, it is recommended to equip them with necessary skills to confidently carry out a range of interpersonal and proactive task. Supported by Axtell et al., (2003), training involving interpersonal skills such as team building or technical mastery 
INTERNATIONAL JOURNAL OF ACADEMIC RESEARCH IN BUSINESS AND SOCIAL SCIENCES

Vol. 10, No. 7, July, 2020, E-ISSN: 2222-6990 @ 2020 HRMARS

which requires employees to be competent and take precautions before problems arise in the workplace is a tool for enhancing employees RBSE.

Another important issue to ponder is, to determine the type of training that is suitable to enhance RBSE. Either voluntary or compulsory training which is important to be distinguished. Leaders need to look at whether the training is self-initiated or leader directed. Consistent with self-determination theory and past studies, self-initiated trainings could enhance RBSE more than compulsive training as employees tend to feel more motivated in former case. Future studies are suggested to focus on these possibilities to enhance teachers RBSE for a more proactive work behaviour employee. As PWB is benefical to both school organizations and teachers, school principals may want to encourage their teachers to be proactive.

Generally, exploring the concept of RBSE can add valueable literature on proactive work behaviour of teachers within the school context and significantly help to enrich the professional lives of teachers in school by serving as a knowledge resource and realize the importance of being proactive. This review reinforces existing theories by providing in-depth information on the observed relationship between RBSE and PWB. Grounded on Self-determination Theory (Deci \& Ryan, 1985) and its Motivation Model for Workplace (Deci, Olafsen \& Ryan, 2017) and Motivation Model of Proactive Work Behavior by (Parker, Bindle, \& Strauss ,2010) this review suggest RBSE have effect on teachers' Proactive Work Behavior (PWB) that is influenced by proactive motivational states and goal process. It is a significant contribution to existing literature by placing RBSE as a way through to teacher PWB in school organizations. RBSE influences teacher PWB is explained within SDT as the central concept for behavioral change (Deci \& Ryan, 2017) and further strengthen the Motivation Model for workplace developed by (Deci, Olafsen \& Ryan, 2017) and Motivation Model of Proactive Work Behavior developed by Parker, Bindl, and Strauss (2010). Contextually the review suggests that one way of promoting PWB among teachers is to develop teacher self-efficacy to a broader perspective RBSE. It has become very important to understand what influences teacher's RBSE to cope with more challenging task related to their professional work (Caprara et al.,2006; Tschannen-Moran and Hoy, 2007). For that reason, teacher's personal values maybe something of great importance to explore in school context. Teachers self-determination may activate teacher's personal values and related behaviors, thus strengthening their RBSE.

\section{References}

Axtell, C. M., Holman, D. J., Unsworth, K. L., Wall, T. D., Waterson, P. E., \& Harrington, E. (2000). Shopfloor innovation: Facilitating the suggestion and implementation of ideas. Journal of Occupational and Organizational Psychology, 73, 265-285. https://org.doi:10.1348/096317900167029

Axtell, C. M., \& Parker, S. K. (2003). Promoting role breadth self-efficacy through involvement, work redesign and training. Human Relations, 56(1), 113-

131. https://doi.org/10.1177/0018726703056001452

Bandura, A. (1982). Self-efficacy mechanism in human agency. American Psychologist, 37, 122-147.

Bandura, A. (1986). Social foundations of thought and action: A social-cognitive view. Englewood Cliffs, NJ: Prentice Hall.

Bandura, A. (1997) Self-Efficacy: The exercise of control. NY. W.H. Freeman and Company. 
INTERNATIONAL JOURNAL OF ACADEMIC RESEARCH IN BUSINESS AND SOCIAL SCIENCES

Vol. 10, No. 7, July, 2020, E-ISSN: 2222-6990 @ 2020 HRMARS

Barling, J., \& Beattie, R. (1983). Self-efficacy beliefs and sales performance. Journal of Organizational Behaviour Management, 5, 41-51.

Bartol, K. M., \& Martin, D. C. (1998). Management. Mcgraw-Hill College.

Bateman, T. S., \& Crant, J. M. (1993). The proactive component of organizational behavior: A measure and correlates. Journal of Organizational Behavior, 14(2), 103-118.

Belchak, F. D., \& Hartog, D. D. N. (2010). Pro-self, prosocial, and pro-organizational foci of proactive behavior: Differential antecedents and consequences. Journal of Occupation and Organizational Psychology, 83, 475-498. doi: 10.1346/096317909X439208

Bindl, U. K., Parker, S. K., Totterdell, P., \& Hagger-Johnson, G. (2012). Fuel of the self-starter: How mood relates to proactive goal regulation. Journal of Applied Psychology, 97(1), 134150. https://doi.org/10.1037/a0024368

Bray-Clark, N., \& Bates, R. (2003). Self-efficacy beliefs and teacher effectiveness: Implications for professional development. Professional Educator, 26(1), 13-22.

Brockner, J. (1988). Self-esteem at work: Theory, research, and practice. Lexington, MA: Lexington Books.

Buchanan, D. A., \& McCalman, J. (1989). High performance work systems: The digital experience. Surrey, England: Routledge.

Cerit, Y. (2017). The mediating effect of LMX in the relationship between school bureaucratic structure and teachers' proactive behavior. Leadership \& Organization Development Journal, 38(6), 780-793. https://doi.org/10.1108/LODJ-01-2016-0005

Crant, J. M. (2000). Proactive behavior in organizations. Journal of Management, 26(3), 435-462.

Dean, J. W., \& Snell, S. A. (1991). Integrated manufacturing and job design: Moderating effects of organizational inertia. Academy of Management Journal, 34, 774-804.

DeCharms, R. (1968). Personal causation: The internal affective determinants of behavior. New York: Academic Press.

Deci, E. L., \& Ryan, R. M. (1985). Intrinsic motivation and self-determination in human behavior. New York: Plenum

Deci, E. L., Olafsen, A. H., \& Ryan, R. M. (2017). Self-determination theory in work organizations: The state of a science. Annual Review of Organizational Psychology and Organizational Behavior, 4, 19-43. doi: 10.1146/annurev-orgpsych-032516-113108.

Deci, E. L., \& Vansteenkiste, M. (2004). Self-determination theory and basic need satisfaction: Understanding human development in positive psychology. Ricerche di Psicologia, 27(1), 2340.

Den Hartog, D.N., \& Belschak, F.D. (2012). When does transformational leadership enhance employee proactive behavior? The role of autonomy and role breath self-efficacy. Journal of Applied Psychology, 97, 194-202.

Devonport, T. J., Biscomb, K., \& Lane, A. M. (2010). Sources of stress and the use of anticipatory, preventative and proactive coping strategies by higher education lecturers. Journal of Hospitality, Leisure, Sport and Tourism Education, 7 (1), $70-81$.

DiPaola, M. F., \& Hoy, W. K. (2005). Organizational citizenship of faculty and achievement of high school students. The High School Journal, 88, 35-44.

Fay, D., \& Frese, M. J. (2001). The concept of personal initiative: an overview of validity studies. Human Performance, 14, 124 - 97. 
INTERNATIONAL JOURNAL OF ACADEMIC RESEARCH IN BUSINESS AND SOCIAL SCIENCES

Vol. 10, No. 7, July, 2020, E-ISSN: 2222-6990 @ 2020 HRMARS

Fay, D., \& Sonnentag, S. (2012). Within-person fluctuations of proactive behavior: How affect and experienced competence regulate work behavior. Human Performance, 25(1), 72-93. https://doi.org/10.1080/08959285.2011.631647

Fisher, C. D. (1978). The effects of personal control, competence, and extrinsic reward systems on intrinsic motivation. Organizational Behavior \& Human Performance, 21(3), 273-288.

Ford, M. E. (1992). Motivating humans. Goals, emotions, and personal agency beliefs. Newbury Park, CA: SAGE Publications, Inc.

Frayne, C. A., \& Latham, G. P. (1987). Application of social learning theory to employee selfmanagement of attendance. Journal of Applied Psychology. 72. 387-392. 10.1037/00219010.72.3.387.

Frese, M., \& Fay, D. (2001). Personal leadership: An active performance concept for work in the 21st century. Research in Organizational Behavior, 23, 133-187.

Frese, M., Kring, W., Soose, A., \& Zempel, J. (1996). PI at work: Differences between East and West Germany. Academy of Management Journal, 39, 37-63.

George, J. M., and Brief, A. P. (1992) Feeling good-doing well: A conceptual analysis of the mood at work-organizational spontaneity relationship. Psychology Bulletin, 112, 310-329. http://doi.org/10.1037/0033-2909.112.2.310

Ghitulsescu, B. E. (2013). Making change happen: The impact of work context on adaptive and proactive behaviors. The Journal of Applied Behavioral Science, 49, 206-245.

Gist, M. E., Schwoerer, C., \& Rosen, B. (1989). Effects of alternative training methods on self-efficacy and performance in computer software training. Journal of Applied Psychology, 74(6), 884891. https://doi.org/10.1037/0021-9010.74.6.884

Gist, M. E. (1989). The influence of training method on self-efficacy and idea generation among managers. Personnel Psychology, 42, 787-805.

Grant, A. M., \& Ashford, S. J. (2008). The dynamics of individual job at work. Research in Organizational Behavior, 28, 3-34.

Greguras, G. J., \& Diefendorff, J. M. (2009). Different fits satisfy different needs: Linking personenvironment fit to employee commitment and performance using self-determination theory. Journal of Applied Psychology, 94(2), 465-477.http://dx.doi.org/10.1037/a0014068

Griffin, M. A., Neal, A., \& Parker, S. K. (2007). A new model of work role performance: Positive behavior in uncertain and interdependent contexts. The Academy of Management Journal, 50(2), 327-347.

Griffin, M. A., Parker, S. K., \& Neal, A. (2002). An integrative model of individual work performance. Heights, MA: Allyn \& Bacon.

Hill, T., Smith, N. D., \& Mann, M. F. (1987). Role of efficacy expectations in predicting the decision to use advanced technologies: The case of computers. Journal of Applied Psychology, 72(2), 307313.http://dx.doi.org/10.1207/s15327043hup1002_7

Lent, R. W., Brown, S. D., \& Larkin, K. C. (1987). Comparison of three theoretically derived variables in predicting career and academic behaviour: Self-efficacy, interest congruence, and consequence thinking.Journal of Counselling Psychology, 34(3), 293298.http://dx.doi.org/10.1037/0022-0167.34.3.293

Locke, E. A., \& Latham, G. P. (1990). A theory of goal setting and task performance. Englewood Cliffs, NJ: Prentice Hall. 
INTERNATIONAL JOURNAL OF ACADEMIC RESEARCH IN BUSINESS AND SOCIAL SCIENCES

Vol. 10, No. 7, July, 2020, E-ISSN: 2222-6990 @ 2020 HRMARS

Morrison, E. W., \& Phelps, C. C. (1999). Taking charge at work: Extrarole efforts to initiate workplace change. Academy of Management Journal, 42(4), 403-419. https://doi.org/10.2307/257011

Ohly, S., \& Fritz, C. (2007). Challenging the status quo: What motivates proactive behavior? Journal of Occupational and Organizational Psychology, 80(4), 623-629. https://doi.org/10.1348/096317907X180360

Parker, S. K., \& Collins, C. G. (2010). Taking Stock: Integrating and differentiating multiple proactive behaviors. Journal of Management, 36(3), 633-662. https://doi.org/10.1177/0149206308321554

Parker, S. K. (1998). Enhancing role breadth self-efficacy: The roles of job enrichment and other organizational interventions. Journal of Applied Psychology, 83(6), 835852. https://doi.org/10.1037/0021-9010.83.6.835

Parker, S. K., Bindle, U. K., \& Strauss, K. (2010). Making Things Happen: A Model of Proactive Motivation. Journal of Management, 36, 827-856.

Parker, S. K., Williams, H. M., \& Turner, N. (2006). Modeling the antecedents of proactive behavior at work. Journal of Applied Psychology, 91(3), 636-652. https://doi.org/10.1037/00219010.91.3.636

Parker, S. K., \& Bindl, U. K. (2017). Proactivity at work: a big picture perspective on a construct that matters. In: Parker, S.K. \& Bindl, U.K., (eds.) Proactivity at work making things happen in organizations. Routledge, New York, USA. ISBN 9781848725638

Parker, S. K. (2000). From passive to proactive motivation: The importance of flexible role orientations and role breadth self-efficacy. Applied Psychology: An International Review, 49(3), 447469. https://doi.org/10.1111/1464-0597.00025

Rank, J., Pace, V., \& Frese, M. (2004). Three avenues for future research on creativity, innovation, and initiative. Applied Psychology an International Review, 53(4), 518- 528.

Reeve, J. (1996). Motivating others: Nurturing inner motivational resources. Needham

Richards, J. C., \& Schmidt, R. (2002). Longman dictionary of language teaching and applied linguistics. Edinburgh Gate: Pearson Education Limited.

Russell, J. A. (2003). Core affect and the psychological construction of emotion. Psychological Review, 110(1), 145-172. https://doi.org/10.1037/0033-295X.110.1.145

Ryan, R. M. (1982). Control and information in the intrapersonal sphere: An extension of cognitive evaluation theory. Journal of Personality and Social Psychology, 43, 450-461.

Ryan, R. M., \& Deci, E. L. (2017). Self-determination theory. Basic psychological needs in motivation, development and wellness. New York: Guilford Publishing.

Ryan, R., \& Deci, E. (2000). Self-determination theory and the facilitation of intrinsic motivation, social development and well-being. American Psychologist, 55, 68-78.

Scott, S. G., \& Bruce, R. A. (1994). Determinants of innovative behavior: A path model of individual innovation in the workplace. Academy of Management Journal, 37(3), 580607. https://doi.org/10.2307/256701

Seibert, S. E., Crant, J. M., \& Kraimer, M. L. (1999). Proactive personality and career success. Journal of Applied Psychology, 84(3), 416-427.http://dx.doi.org/10.1037/0021-9010.84.3.416

Sheard, J. I., \& Carbone, A. (2008). ICT teaching and learning in a new educational paradigm: lecturers' perceptions versus students' experiences. Australian Computer Society, Inc. Conferences in Research and Practice in Information Technology, Vol. 88. 
INTERNATIONAL JOURNAL OF ACADEMIC RESEARCH IN BUSINESS AND SOCIAL SCIENCES

Vol. 10, No. 7, July, 2020, E-ISSN: 2222-6990 @ 2020 HRMARS

Siegel, D. S., \& Renko, M. (2012). The role of market and technological knowledge in recognizing entrepreneurial opportunities. Management Decision, 50(5), 797-

816. https://doi.org/10.1108/00251741211227500

Sinden, J., Jones, R., Hester, S., Odom, D., Kalisch, C., James, S. R., \& Cacho, O. (2004). The economic impact of weeds in Australia.

Speier, C., \& Frese, M. (1997). Generalized self-efficacy as a mediator and moderator between control and complexity at work and personal initiative: A longitudinal field study in East Germany. Human Performance, 10(2), 171-192.

Strauss, K., \& Parker, S. K. (2014). Effective and sustained proactivity in the workplace: A selfdetermination theory perspective. In M. Gagne (Ed.) Oxford handbook of work engagement, motivation, and self-determination theory. New York: Oxford University Press.

Strauss, K., Griffin, M. S., \& Rafferty, A. E. (2009). Proactivity directed toward the team and organization: The role of leadership, commitment and role-breadth self-efficacy. British Journal of Management, 20(3), 279-291.

Strauss, V. (2015). The real reasons behind the U.S. teacher shortage, Washington Post, August 24, 2015.

Ling, T. P., Pihie, Z. A., Asimirin, S., \& Fooi, F. S. (2015). The influence of transformational school leadership on teacher efficacy in Malaysian secondary school teachers. International Journal of Social Science Research, 3(2), 73-85.

Van Dyne, L., \& LePine, J. A. (1998). Helping and voice extra-role behaviors: Evidence of construct and predictive validity. Academy of Management Journal, 41(1), 108119. https://doi.org/10.2307/256902

Withey, M., \& Cooper, W. (1989). Predicting exit, voice, loyalty, and neglect. Administrative Science Quarterly, 34(4), 521-539

Wood, R. E., George-Falvy, J., \& Debowski, S. (2001). Motivation and Information Search on Complex Tasks. In M. Erez, U. Klienbeck, \& H. Thierry (Eds.), Work Motivation in the Context of a Globalising Economy (pp. 27 - 48). Erlbaum.

Zhang, Z., Wang, M., \& Shi, J. (2012). Leader-follower congruence in proactive personality and work outcomes: The mediating role of leader-member exchange. Academy of Management Journal, 55(1), 111-130. https://doi.org/10.5465/amj.2009.0865 